УДК 614.2 "71":656.2(477)

МЕХАНІЗМ ЗАБЕЗПЕЧЕННЯ РОЗВИТКУ ЗАКЛАДІВ ОХОРОНИ ЗДОРОВ’Я АТ «УКРЗАЛІЗНИЦЯ»

DOI 10.32782/2224-6282/152-11

JEL: I10, L20, L92

Головаш О. В.

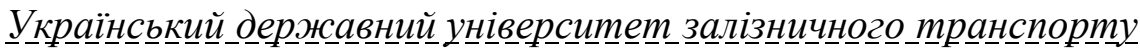
В статті розкрито механізм забезпечення розвитку закладів охорони здоров'я АТ «Укрзалізниця», надано авторське визначення поняття механізм розвитку. Механізм забезпечення розвитку закладів охорони здоров'я базується на виділенні цільової, виробничої, інноваційної, фінансової та інформаційної підсистем. Визначено, що на механізм забезпечення розвитку закладів охорони здоров’я впливають інформаційні потоки 3 зовнішнього середовища підприємства та внутрішні фактори, обумовлені рівнем розвитку стратегічного потенціалу закладу. Цільова підсистема забезпечення розвитку закладів охорони здоров'я включає стратегічні цілі, завдання, основні критерії оцінювання можливостей закладу та принципи. Виробнича підсистема відповідає безпосередньо за розвиток закладів охорони здоров'я шляхом реалізації стратегії розвитку, комплексу заходів щодо підвищення ефективності діяльності. Інноваційна підсистема представлена сукупністю інструментів, які сприяють здійсненню інноваційної діяльності. Основне завдання фінансової підсистеми полягає в забезпеченні процесу розвитку фінансовими ресурсами. Основним завданням інформаційної підсистеми є забезпечення процесу розвитку, розробки та впровадження інноваційних медичних технологій необхідною достовірною інформацією. Ключовими інструментами забезпечення розвитку визначено Центр медичних технологій, Інвестиційний фонд розвитку та Віртуальний центр охорони здоров’я. Важливим інструментом забезпечення належного рівня розвитку закладів охорони здоров'я визначено організацію «віртуального центру охорони здоров'я» - певного інтернет-простору, який, 3 одного боку, буде надавати можливості різним категоріям учасників лікувально-діагностичного процесу всіх закладів охорони здоров’я АТ «Укрзалізниця», а з іншого, забезпечить всіх учасників інноваційних процесів необхідною інформацією щодо впровадження інноваційної технологій. Розкрито основні цілі, завдання, особливості функціонування віртуального центру охорони здоров'я в аспекті забезпечення лікувальнодіагностичного процесу та в аспекті забезпечення процесу створення замкнутого циклу розробки та впровадження інноваційних медичних технологій.

Ключові слова: механізм забезпечення; заклади охорони здоров'я; розвиток; віртуальний центр охорони здоров'я; інструментарій розвитку; АТ «Укрзалізниця»

(C) Головаш О. В., 2019 
UDC 614.2 "71":656.2(477)

\section{MECHANISM OF PROVIDING THE DEVELOPMENT OF HEALTH INSTITUTIONS OF JSC «UKRZALIZNITSA»}

DOI 10.32782/2224-6282/152-11

JEL: I10, L20, L92

\section{Golovash $\mathbf{O}$.}

Ukrainian State University of Railway Transport

The mechanism of ensuring the development of health facilities of JSC "Ukrzaliznytsya" has been described in the article, the author's definition of the concept of the mechanism of development has been provided. The mechanism for ensuring the development of health care facilities is based on the allocation of target, production, innovation, financial and information subsystems. It is determined that the mechanism of ensuring the development of health care facilities is influenced by information flows from the external environment of the enterprise and internal factors, due to the level of development of the strategic potential of the institution. The target subsystem for the development of health care facilities includes strategic goals, objectives, basic criteria for assessing the capacity of the institution, and principles. The production subsystem is directly responsible for the development of healthcare facilities through the implementation of a development strategy, a set of measures to improve the efficiency of operations. The innovation subsystem is represented by a set of tools that facilitate innovation. The main task of the financial subsystem is to ensure the process of development of financial resources. The main task of the information subsystem is to provide the process of development, development and implementation of innovative medical technologies with the necessary reliable information. Key tools for development are identified by the Medical Technology Center, the Development Investment Fund, and the Virtual Health Center. An important tool for ensuring the proper level of development of health care institutions is the organization of a "virtual health center" - a certain Internet space, which, on the one hand, will provide opportunities for different categories of participants of the medical and diagnostic process of all health care facilities Ukrzaliznytsia, on the other hand, will provide all participants of innovation processes with the necessary information on the introduction of innovative technologies. The basic goals, tasks, peculiarities of functioning of the virtual health center in the aspect of providing the medical-diagnostic process and in the aspect of providing the process of creating a closed cycle of development and introduction of innovative medical technologies are revealed.

Keywords: mechanism of provision; health care facilities; development; virtual health center; development tools; JSC "Ukrzaliznytsia"

Актуальність. Забезпечення розвитку закладів охорони здоров'я на основі стратегічного підходу базується на активізації стратегічного потенціалу закладів охорони здоров'я, впровадження медичних інновацій. Недостатність фінансових ресурсів, необхідність формування замкнутого циклу розробки та впровадження інноваційних медичних 
технологій потребують розроблення механізму, який дозволить сформувати модель взаємодії інноваційних, фінансових, інформаційних процесів в закладах охорони здоров’я з науково-дослідними установами, закладами вищої освіти, які приймають участь в розробці інноваційних технологій та практичною медициною.

Аналіз останніх наукових досліджень та публікацій. Питанням розвитку закладів охорони здоров'я, удосконаленню механізмів їх розвитку присвячено роботи С.М., Вовк, Н.Р.Готь, Г.О. Слабкого, О. О. Дорошенко, Л.В. Журавльової, О.В. Корабльової, М.А. Буранкової, О.П. Корнійчука, О.П. Маслової, А.В. Вавілова, О. А.Фохта, Ю. В. Козадоя, А. А. Цветкова [1-8] та ін. Однак, в сучасних умовах функціонування розвиток закладів охорони здоров’я АТ «Укрзалізниця» потребує формування механізму та визначення інструментарію забезпечення розвитку, які дозволять організувати раціональне інформаційне, інноваційне, фінансове забезпечення розвитку закладів охорони здоров’ я, що і обумовило мету статті.

Виклад основних результатів дослідження. Механізм забезпечення розвитку закладів охорони здоров'я АТ «Укрзалізниця»є складовою системи розвитком АТ «Українська залізниця» та являє собою сукупність взаємодіючих інструментів, які визначаються функціями, принципами, формами та методами організації процесу інноваційної, інвестиційної діяльності, спрямованими на впровадження медичних технологій в закладах охорони здоров’я.

Всі складові елементи механізму знаходяться у взаємозв'язку та мають взаємний вплив (рис. 1). Механізм забезпечення розвитку закладів охорони здоров'я спрямований на ефективне управління процесом розвитку закладом.

На механізм забезпечення розвитку закладів охорони здоров'я впливають інформаційні потоки з зовнішнього середовища підприємства та внутрішні фактори, обумовлені рівнем розвитку стратегічного потенціалу закладу. У структурі механізму слід виділити наступні підсистеми.

Цільова підсистема забезпечення розвитку закладів охорони здоров’я включає стратегічні цілі, завдання, основні критерії оцінювання можливостей закладу та принципи.

Стратегічною метою розвитку закладів охорони здоров'я $\epsilon$ підвищення рівня безпеки на залізничному транспорті та дотримання стандартів охорони здоров'я та безпеки співробітників відповідно до міжнародних практик. 


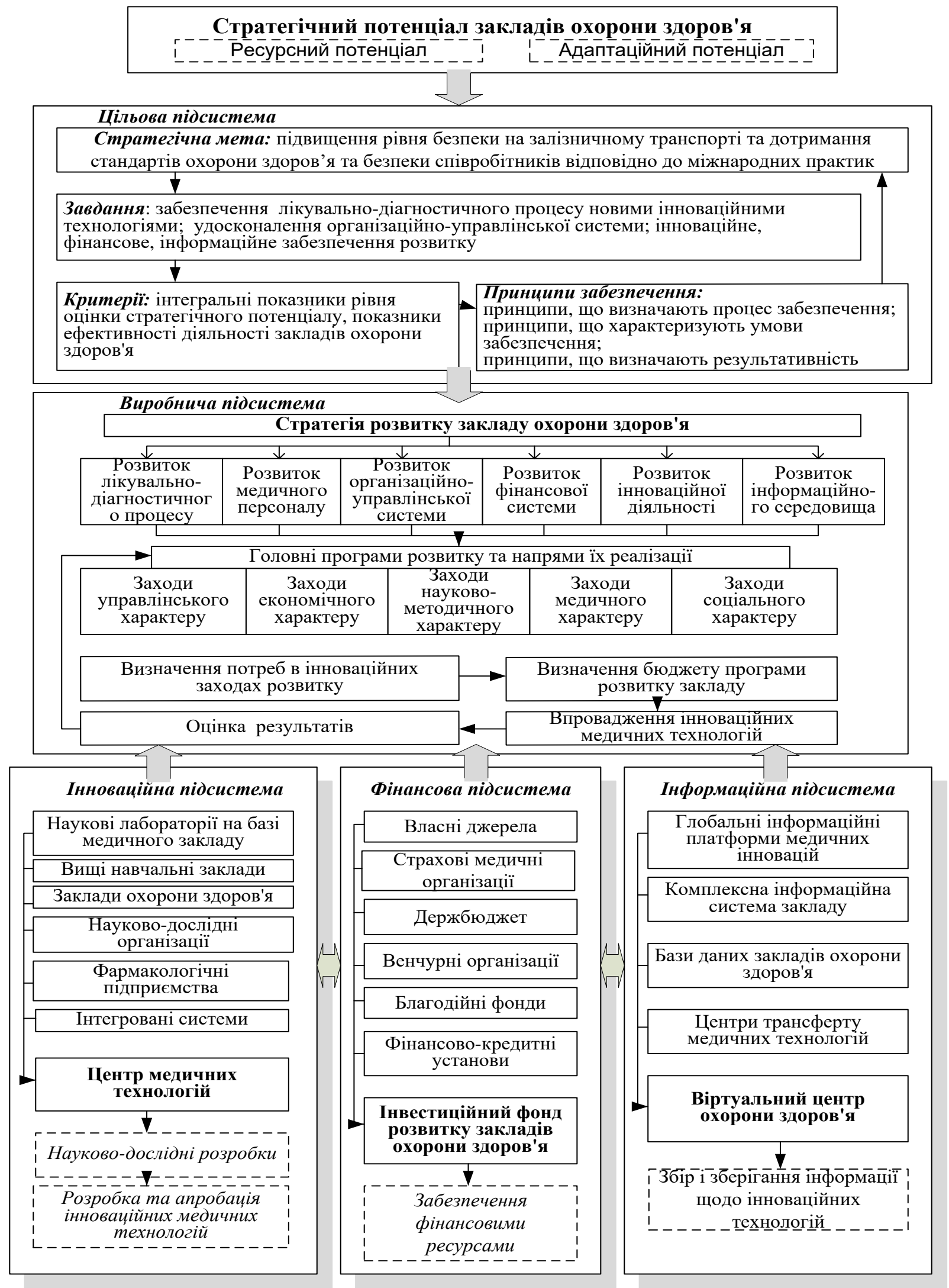

Pис. 1 Складові механізму забезпечення розвитку закладів охорони здоров'я AT «Укрзалізниия»

Джерело: авторська розробка 
Завдання полягають в забезпеченні лікувально-діагностичного процесу новими інноваційними технологіями; удосконаленні організаційно-управлінської системи; інноваційному, фінансовому та інформаційному забезпечення розвитку.

Критеріями виступають інтегральні показники рівня оцінки стратегічного потенціалу, показники ефективності діяльності закладів охорони здоров'я.

Виробнича підсистема відповідає безпосередньо за розвиток закладів охорони здоров'я шляхом реалізації стратегії розвитку, комплексу заходів щодо підвищення ефективності діяльності.

Основними підсистемами, що забезпечують процес розвитку закладів охорони здоров'я $є$ інноваційна, фінансова та інформаційна підсистеми.

Інноваційна підсистема представлена сукупністю інструментів, які сприяють здійсненню інноваційної діяльності. До складу підсистеми входять наукові лабораторії, що функціонують на базі медичного закладу, вищі заклади вищої освіти, які продоять спільну практичну діяльність на базі медичного закладу, науково-дослідні організації, які проводять дослідження в галузі медицини, фармакологічні підприємства, науково-виробничі інтегровані структури. Кооперація інноваційного потенціалу та інноваційної діяльності зазначених підприємства доцільно здійснювати на основі формування Центру медичних технологій [9]. Це дозволить створити замкнутий цикл розробки та впровадження медичних інноваційних технологій та отримати синергетичний ефект від трансферту технологій.

Наступною складовою механізму забезпечення розвитку $\epsilon$ фінансова підсистема. Основне завдання підсистеми полягає в забезпеченні процесу розвитку фінансовими ресурсами. Джерелами впровадження заходів щодо розвитку закладу повинні бути власні кошти, залучені (іноземні та вітчизняні інвестори), залучення коштів венчурних організацій, залучені кошти благодійних організацій та інвестиційний фонд розвитку закладів охорони здоров'я.

Залучення та раціональне використання фінансових ресурсів пропонуємо здійснювати на основі формування Інвестиційного фонду розвитку закладів охорони здоров'я. Основним завданням зазначеного фонду є накопичення фінансових ресурсів з боку держави, підприємств комерційного сектору, приватних інвесторів, які на проектній основі будуть направлені на розробку та впровадження інноваційних медичних технологій як в закладах охорони здоров'я АТ «Укрзалізниця», так і медичній галузі в цілому. Накопичені кошти будуть знаходитися на 
рахунках Фонду та повинні використовуватися за цільовим призначенням 3 максимальною безпекою та рентабельністю [10].

Основним завданням інформаційної підсистеми $є$ забезпечення процесу розвитку, розробки та впровадження інноваційних медичних технологій необхідною достовірною інформацією. Важливим інструментом забезпечення належного рівня розвитку закладів охорони здоров'я є організація «віртуального центру охорони здоров'я» формування певного інтернет-простору, який, з одного боку, буде надавати можливості різним категоріям учасників лікувально-діагностичного процесу всіх закладів охорони здоров’я АТ «Укрзалізниця», а 3 іншого, забезпечить всіх учасників інноваційних процесів необхідною інформацією щодо впровадження інноваційної технологій.

Єдина інформаційна система - «віртуальний центр охорони здоров’я» представляє собою сукупність інформаційно-технологічних і технічних засобів і сервісів, що забезпечують інформаційну підтримку методичного та організаційного забезпечення діяльності учасників процесу охорони здоров'я.

Основними цілями об'єднання лікувально-діагностичних ресурсів $\epsilon$ :

- забезпечення ефективної інформаційної підтримки процесу управління системою медичної допомоги, а також процесу надання медичної допомоги;

- забезпечення інформаційної підтримки процесу розробки та впровадження інноваційних медичних технологій.

Таке об'єднання дозволить забезпечити вирішення комплексу задач за наступними напрямками:

в аспекті забезпечення лікувально-діагностичного процесу:

- підвищення ефективності управління в сфері охорони здоров'я на основі інформаційно-технологічної підтримки вирішення завдань прогнозування і планування витрат на надання медичної допомоги, а також контролю за дотриманням державних гарантій за обсягом і якістю ii надання;

- підвищення якості надання медичної допомоги на основі вдосконалення інформаційно-технологічного забезпечення діяльності медичних і фармацевтичних організацій, їх персоналу, учнів медичних і фармацевтичних установ;

- підвищення інформованості населення з питань ведення здорового способу життя, профілактики захворювань, отримання медичної допомоги, якості обслуговування в медичних організаціях, а також здійснення діяльності в сфері охорони здоров'я на основі забезпечення 
можливостей електронної взаємодії 3 відповідними уповноваженими органами;

в аспекті забезпечення процесу створення замкнутого циклу розробки та впровадження інноваційних медичних технологій:

- підвищення ефективності управління на основі інформаційнотехнологічної підтримки 3 питань розробки та впровадження інноваційних медичних технологій;

- підвищення якості інноваційного продукту, якості процесу розробки та впровадження на основі вдосконалення інформаційнотехнологічного забезпечення діяльності учасників формування замкнутого циклу розробки та впровадження інноваційних медичних технологій.

«Віртуальний центр охорони здоров'я» як засіб об'єднання лікувально-діагностичних ресурсів і індивідуального ведення пацієнта на основі порталу пацієнта реалізує широкий спектр взаємодії з пацієнтом, лікарями, медичними установами та агентами, які просувають медичні послуги.

Діяльність «Віртуального центру охорони здоров'я» повинна базуватися на досвіді інформатизації медичних організацій і включати:

в аспекті забезпечення лікувально-діагностичного процесу:

- отримання, передача в центр обробки і зберігання даних про стан здоров'я пацієнтів з різних джерел, включаючи портативні вимірювальні прилади, дані, одержувані з спеціалізованих медичних інформаційних систем, вручну вносяться відомості;

- обробка первинної інформації в центрі обробки даних в ручному, напівавтоматичному і автоматичному режимах з використанням засобів $\mathrm{i}$ методів інженерії знань, включаючи алгоритми експертних систем, систем, заснованих на знаннях, і методів прецедентного аналізу;

- скринінгове визначення стану здоров'я пацієнта згідно з аналізом моделі пацієнта, визначення факторів ризику і формування рекомендацій по режиму, дієті i необхідним діагностичним i лікувальнопрофілактичних заходів, включаючи консультації фахівців;

- забезпечення середовища телекомунікаційного взаємодії «Лікар пацієнт» для виконання онлайн-консультацій і надання індивідуальних сервісів, пов'язаних з веденням пацієнта, включаючи консультації 3 виконання пацієнтом лікувально-охоронного режиму, розшифровку наданих пацієнтом результатів обстежень, очних і заочних консультацій;

- надання засобів формувань напрямків на очний прийом в лікувально-діагностичні заклади для виконання консультацій, 
госпіталізації або проведення реабілітаційних заходів з наданням доступу до накопичених об'єктивними показниками стану здоров'я пацієнта;

- реалізація майданчиків просування медичних послуг різних лікувально-профілактичних закладів на порталі за рахунок надання пацієнтам контекстно-залежних відомостей про рекомендованих лікувально-діагностичних заходах, показаних при виявлених в результаті скринінг-тестування відхилень в стані здоров'я пацієнта;

- ведення інформаційно-довідкових ресурсів з підтримки здорового способу життя, які роз'яснюють надані рекомендації;

в аспекті забезпечення процесу створення замкнутого циклу розробки та впровадження інноваційних медичних технологій:

- отримання, передача в центр обробки i зберігання даних про інноваційні розробки закладів охорони здоров'я, результати доклінічних, клінічних досліджень, результати впровадження інноваційних медичних технологій в лікувально-діагностичний процес;

- реалізація майданчиків для обміну досвіду щодо розробки та впровадження медичних інновацій;

- забезпечення середовища телекомунікаційної взаємодії учасників розробки та впровадження інноваційних медичних технологій.

Ключовими особливостями «Віртуального центру охорони здоров'я» $\epsilon$ комплексна робота з пацієнтом над виявленням відхилень в стані здоров'я, надання якісних сервісів по діагностики та лікування виявлених захворювань, комплексна робота по забезпеченню процесу розробки та впровадження інноваційних медичних технологій необхідними інформаційними ресурсами.

Організація «Віртуального центру охорони здоров'я» полягає в об'єднанні засобів портальних технологій, медичних інформаційних систем та індивідуальних засобів моніторингу здоров'я, формуванні нових способів взаємодії лікарів та медичних організацій з пацієнтами, інтеграції практично всіх існуючих підходів стеження за здоров'ям пацієнтів в єдиному середовищі, формування нових форм взаємодії учасників процесу розробки та впровадження інноваційних медичних технологій в закладах охорони здоров'я.

«Віртуальний центр охорони здоров'я» може організовувати взаємодію $з$ пацієнтом 3 використанням індивідуальних діагностичних приладів, які здійснюють вимірювання і передачу даних для контролю стану пацієнта.

Схема функціонування системи «Віртуального центру охорони здоров'я» представлено на рис. 2. 


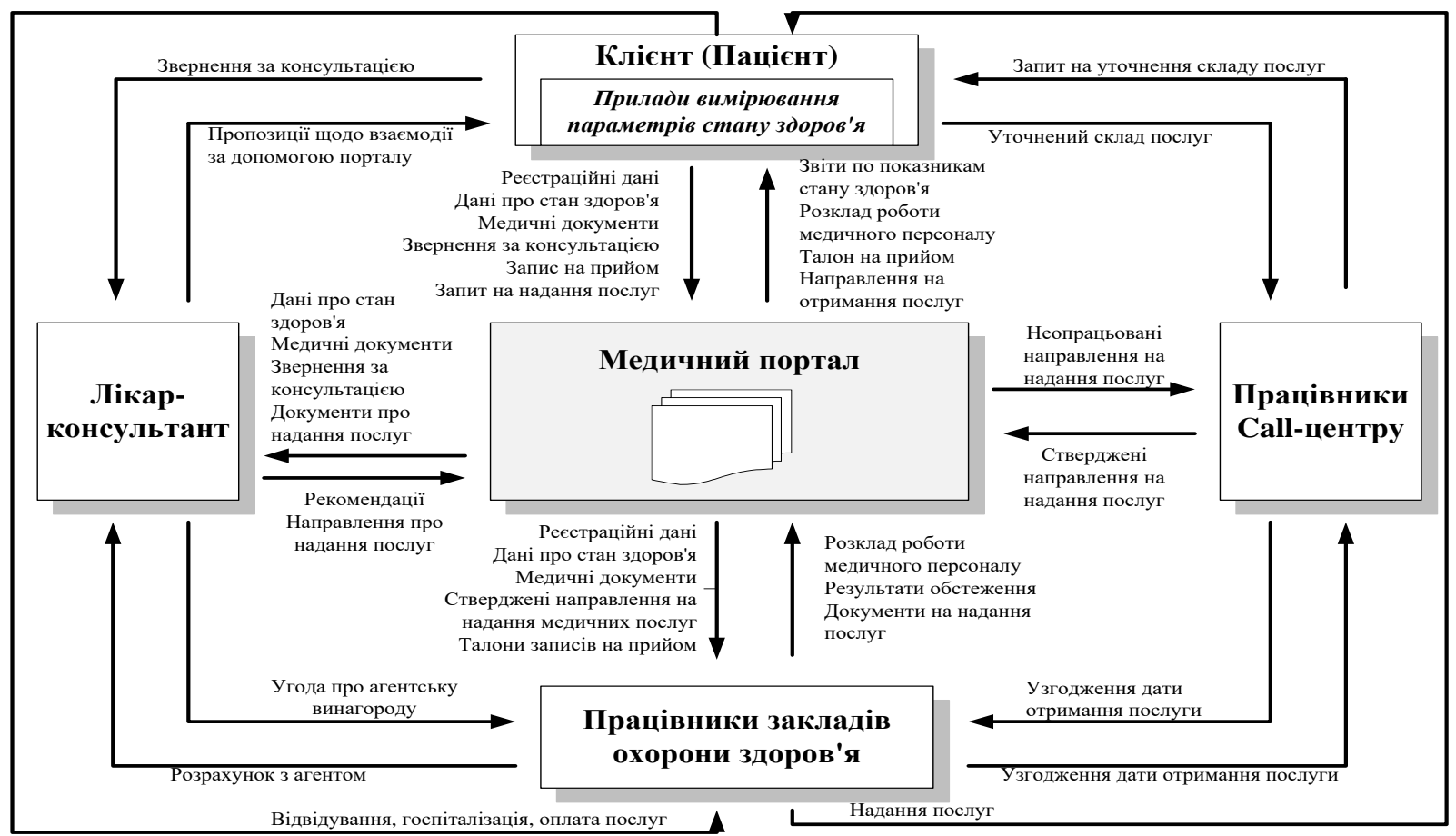

Pис. 2 Схема функиіонування системи «Віртуального ичентру охорони здоров'я» Джерело: авторська розробка

Принципова схема функціонування системи «Віртуального центру охорони здоров'я» описує технологічні процеси надання медичної допомоги пацієнтам, взаємодії лікувальних установ, обліку фактів надання медичних послуг і фіксації економічних характеристик послуг, що надаються.

Принципову схему функціонування «Віртуального центру охорони здоров'я» реалізують моделі персонального ведення пацієнта, що дозволяють формувати план лікувально-профілактичних заходів при наданні медичної допомоги як всередині одного закладу, так і при взаємодії всіх закладів охорони здоров'я АТ «Укрзалізниця».

Висновки. Запропонований механізм забезпечення розвитку закладів охорони здоров'я АТ «Укрзалізниця» включає підсистеми: цільова (у межах якої визначено стратегічну мету, завдання, принципи та критерії забезпечення), виробнича (яка направлена на забезпечення лікувально-діагностичного процесу), інноваційна (яка направлена на розробку та впровадження інноваційних медичних технологій в лікувально-діагностичний процес), інформаційна (направлена на збір та зберігання інформації щодо розробки новітніх технологій, формування Віртуального центру охорони здоров'я), фінансова. Визначені цілі, напрямки діяльності, особливості функціонування, взаємозв'язки, межі взаємодії Віртуального центру охорони здоров'я 3 учасниками 
лікувально-діагностичного процесу дозволять організувати раціональне інформаційне забезпечення розвитку закладів охорони здоров’я.

\section{СПИСОК ВИКОРИСТАНИХ ДЖЕРЕЛ:}

1. Вовк С.М. Механізми державного управління системними змінами у сфері охорони здоров'я : дис.. доктора наук з державного управління: / Вовк Світлана Михайлівна; Донецький державний університет управління. - Маріуполь, 2019 - . 492с.

2. Готь Н.Р. Шляхи інноваційного розвитку обласної клінічної лікарні в умовах реформування системи охорони здоров'я / Н.Р.Готь, Г.О. Слабкий // Актуальні проблеми клінічної та профілактичної медицини. - 2013 - том 1 - С. 34-38

3. Дорошенко О. О. Сучасний стан фінансово-економічного забезпечення медичної допомоги на вторинному рівні / О. О. Дорошенко // Державне управління: удосконалення та розвиток. - 2017. - №2. - - Режим доступу: http://www.dy.nayka. com.ua/?op=1\&z=1038

4. Журавлева Л.В. Повышение доступности и качества услуг здравоохранения в зарубежных странах / Л.В. Журавлева, О.В. Кораблева, М.А. Буранкова // Национальные интересы: приоритеты и безопасность. - 2015. - № 5 (290). - С. 33-44

5. Корнійчук О.П. Удосконалення економічного механізму розвитку первинної медико-санітарної допомоги в Україні / О.П.Корнійчук - Режим доступу: https://www.umj.com.ua/article/34166/udoskonalennya-ekonomichnogo-mexanizmurozvitku-pervinnoi-mediko-sanitarnoi-dopomogi-v-ukraini

6. Маслова О.П. Разработка концепции и бизнес-плана развития лечебного учреждения / О.П. Маслова, А.В. Вавилов - Режим доступа: https://cyberleninka.ru/article/n/ razrabotka-kontseptsii-i-biznes-plana-razvitiya-lechebnogo-uchrezhdeniya

7. Фохт О. А. Динамика формирования и текущее состояние требований по защите персональных данных пациентов / О. А.Фохт, Ю. В. Козадой // Врач и информационные технологии: - 2011. - № 4. -С. 6-22

8. Фохт О. А. Защита персональных данных. Новое в законодательстве: тенденции, вопросы практического применения в медицинских информационных системах. / О. А.Фохт, А. А. Цветков // Врач и информационные технологии. - 2013. - № 5.. C. 44-51.

9. Holovash O. Medical innovation center - innovative instruments for providing development of health institutions of ukrainian railway JSC/ O.Holovash, O.Ievsieieva // Sciences of Europe. - VOL 5, - No 45 (2019), - p 24-27

10. Головаш О.В. Фінансове забезпечення розвитку закладів охорони здоров'я АТ «Українська залізниця» / О.В. Головаш // Вісник економіки транспорту i промисловості. - 2019. - №68. - С. 253-260

\section{REFERENCES:}

1. Vovk S.M. (2019) Mekhanizmy derzhavnoho upravlinnya systemnymy zminamy u sferi okhorony zdorov"ya [Mechanisms of state management of systemic changes in health care] Doctor thesis. Mariupol: Donetsk State University of Management [in Ukrainian]. 
2. Hot' N.R. and Slabkyy H.O. (2013) Shlyakhy innovatsiynoho rozvytku oblasnoyi klinichnoyi likarni v umovakh reformuvannya systemy okhorony zdorov"ya [Ways of innovative development of the regional clinical hospital in the conditions of reforming the health care system] Aktual'ni problemy klinichnoyi ta profilaktychnoyi medytsyny Current problems of clinical and preventive medicine. 1. 34-38 [in Ukrainian].

3. Doroshenko O. O. (2017) Suchasnyy stan finansovo-ekonomichnoho zabezpechennya medychnoyi dopomohy na vtorynnomu rivni [The current state of financial and economic provision of medical care at the secondary level] Derzhavne upravlinnya: udoskonalennya ta rozvytok.- Public administration: improvement and development. 2. - - Retrieved from: http://www.dy.nayka.com.ua/?op=1\&z=1038 [in Ukrainian].

4. Zhuravleva L.V., Korableva O.V. and Burankova M.A. (2015) Povysheniye dostupnosti i kachestva uslug zdravookhraneniya v zarubezhnykh stranakh [Improving the availability and quality of health services in foreign countries]. Natsional'nyye interesy: prioritety $i$ bezopasnost' - National interests: priorities and security 5 (290). 33-44

5. Korniychuk O.P. Udoskonalennya ekonomichnoho mekhanizmu rozvytku pervynnoyi medyko-sanitarnoyi dopomohy $\mathrm{v}$ Ukrayini [Improving the economic mechanism of development of primary health care in Ukraine] Retrieved from: https://www.umj.com.ua/article/34166/udoskonalennya-ekonomichnogo-mexanizmurozvitku-pervinnoi-mediko-sanitarnoi-dopomogi-v-ukraini [in Ukrainian].

6. Maslova O.P. and Vavilov A.V. Razrabotka kontseptsii i biznes-plana razvitiya lechebnogo uchrezhdeniya [Development of a concept and a business plan for the development of a medical institution] / Retrieved from: https://cyberleninka.ru/article/n/razrabotka-kontseptsii-i-biznes-plana-razvitiyalechebnogo-uchrezhdeniya

7. Fokht O. A. and Kozadoy YU. V. (2011) Dinamika formirovaniya i tekushcheye sostoyaniye trebovaniy po zashchite personal'nykh dannykh patsiyentov [Dynamics of formation and the current state of the requirements for the protection of personal data of patients] Vrach i informatsionnyye tekhnologii- Physician and Information Technology 4. 6-22

8. Fokht O. A. and Tsvetkov A. A. (2013) Zashchita personal'nykh dannykh. Novoye v zakonodatel'stve: tendentsii, voprosy prakticheskogo primeneniya $\mathrm{v}$ meditsinskikh informatsionnykh sistemakh. [Protection of personal data. New in the legislation: trends, issues of practical application in medical information systems] Vrach i informatsionnyye tekhnologii - Physician and Information Technologies. 5. 44-51.

9. Holovash O. and Ievsieieva O. (2019)Medical innovation center - innovative instruments for providing development of health institutions of ukrainian railway JSC/ Sciences of Europe. - 5. 45. 24-27 [in Ukrainian].

10. Holovash O.V. (2019) Finansove zabezpechennya rozvytku zakladiv okhorony zdorov"ya AT «Ukrayins'ka zaliznytsya» [Financial support for the development of health facilities of JSC Ukrainian Railways] Visnyk ekonomiky transportu i promyslovosti - Bulletin of the Economics of Transport and Industry. 68. 253-260 [in Ukrainian]. 